\title{
On the Change of Criticism Connotation of Consumption Alienation-- From Marx's Consumption Alienation Criticism to Western Marxism's Consumption Alienation Criticism
}

\author{
Xiaying LV \\ School of Marxism, Zhejiang University, Hangzhou city, Zhejiang Province, China \\ 775987695@qq.com
}

Keywords: Consumption Alienation, Labor Alienation, Marx, Western Marxism

\begin{abstract}
In Marx's age, the main form of alienation is labor alienation; consumption alienation is derived from labor alienation and appears as insufficient consumption. But as time went on, especially after the Second World War, the manifestation of consumption alienation changed from the alienation of insufficient consumption to the alienation of excessive consumption. This shift reflects the transition of the capitalist mode of production and way of exploitation. How to conceive the shift of the main manifestation of alienation from labor alienation and consumption alienation of insufficient consumption to the consumption alienation of excessive consumption? Our answer affects our view of today's capitalist system and Marxist alienation theory.
\end{abstract}

\section{Introduction}

Today, capitalism not only didn't perish, but also seems blooming after the Second World War. This phenomenon is especially manifested in the abundance of commodities in the market, plenty of beautiful things in eyes, and many flourishing cities. People seem can get everything that they need in their daily life. On the surface, the income and living standards of the working class appear to be been improved, and the alienation of the capitalist society seem gradually faded. But in fact the essence of Capitalism has not changed, and alienation is not likely to disappear. Alienation of the Capitalism just updated its pattern of main manifestation from labor alienation to consumption alienation.

\section{Marx's critique of labor alienation}

For the critique of alienations in capitalist society, Marx started from criticizing the alienation of labor. The alienations of capitalist society are Omni-directional alienations and the alienation of labor is the starting point of all kinds of alienations. Marx explicitly pointed out that the normal state of productive labor should be "every one of us in the process of their own production will double affirm oneself and another person"[1], namely double affirmed oneself and double confirmed another person. Double affirm oneself on the one hand refers to the self in the process of labor put to good use of its own essential strength, creatively released their own initiative, and realized the self value and the meaning of existence. Double affirm oneself on the other hand means that oneself also know my labor products can meet other people's needs, so I can not only play my own value in the process of production, but also can reflect the social value of myself in the process. The double affirmation of another person refers to the enjoyment and satisfaction of another person in the process of consuming my creation, which also promotes the formation of another person's essential power. At the same time, by consuming my creation, another person can also create his own creative talents. But in the capitalist society, the "double affirmation of oneself and the other's labor" is no longer the embodiment of the life essence power itself, rather than becoming forced labor in order to survive. The working class has nothing but his manpower, so he can only survive by selling his labor force and working for the capitalist class. Thus, labor alienation phenomenon appeared. 
The core of Marx's theory of alienation is the analysis of "alienated labor". He thinks that the alienation of labor is attributed to the capitalist private ownership and embodied in four interrelated aspects, namely the alienation of workers and their labor products, the alienation of workers and their labor activities, the alienation of workers and their species nature, and the alienation of workers and other people.

First of all, based on the capitalist private ownership, the product of labor that workers have created is not in the service of the workers themselves, but for the capitalists profit service. Namely, the labor products that workers have produced do not belong to themselves. "The objects produced by labor, that is, the products of labor, as a kind of alien existence, as a force that does not depend on the producer, are opposed to labor." [1] Secondly, "alienation not only manifests itself in the results, but also in the production behavior, in the production activity itself." [1] Labor should be the process of self-determination of the person with subjective initiative, which is the embodiment of human essence in the process of self-selection. Under the capitalist system, the labor process of the workers is not in their own control, but is subject to the external capital force. Thirdly, the difference between people and animals lie in that people are conscious existence, it is the subjective initiative determined that "people are existence of species nature"[1]. People can transform the world through creative practice. Nonetheless, alienation phenomena caused by capitalist society split people's free consciousness of production activities, make person subject to capital controls, and "lower people's species nature into maintaining physical survival's tool".[1] People's "species nature" is not in their own hands, but as puppet under the operation of capital logic.

Finally, "when a man is opposed to himself, he is also opposite to others." [1] The essence of human beings is embodied in the free and conscious practice of themselves and the relationship between people. "The alienation of human beings, in general, the relationship people have for themselves must achieve only through the relationship he has with others. Under the condition of alienated labor, everyone observes others according to the scale and relationship he has as a worker. "[1] With himself being alienated, the workers definitely look at others with their alienated glasses, and they are undoubtedly alienated with others.

\section{Marx's critique of the alienation of consumption: insufficient consumption}

"The movement of private property - production and consumption - is an emotional display of the movement that has so far been produced, that is, the realization of the human being or the reality of the human being." [1] Marx's alienation critiques include two dimensions of production alienation and consumption alienation. Among them, the criticism of production alienation is criticized through the kernel of labor. Marx's critique of the alienation of consumption is not the critical focus of Marx's theory of alienation, and his critique of the alienation of consumption is subject to the critique of the alienation of labor.

Consumption is first and foremost to meet the needs of human existence. The primary role of consumption is to constantly produce the living person. "Consumption is also directly produced, just as the consumption of elements and chemicals in nature is the production of plants. Eat and drink product the human body. Any other way of producing people can be said like this. This is the process of "production by consumption"[2]. Through consumption, human life and all human' social relations can be sustained. Without consumption, we can't sustain the survival and development of human beings, and needless to say the existence and development of society. "Consumption, like production, is essentially the production and reproduction of human life."[3]

In the capitalist society, the means of production and the means of livelihood both become capital. Consumption is no longer just for the production and reproduction of human life, but become the instrument of capital appreciation and controlled by the dominance of capital. At this point, consumption is alienated. Consumption alienation means that consumption becomes the tool of unlimited capital appreciation. Consumption is on longer for the people but for capital. The living consumption of workers obeys the capital logic, "workers are often forced to make their own personal consumption affiliated to the production process"[4]. The personal consumption of the 
working class simply converts the subsistence wages into labor forces that can be re-exploited by the capitalists. The consumption of the working class is subject to the minimum consumption for capital production and reproduction. The consumption of workers becomes the means to maintain the operation of their own labor force, thus ensuring the continuous operation of production. The personal consumption of workers is the same as that of the machine, which is subject to the demand of production. Personal consumption is subordinated to capital logic and consumer alienation is inevitable.

The consumption alienation that Marx criticizes is that the capital accumulation logic is only able to maintain the labor force's reproduction. The bourgeoisie only pay the workers of the minimum level of wage to let them survive. So the consumption of workers can only satisfy their basic survival needs, reducing the consumption of workers to the consumption level of animals. This kind of consumption alienation is obvious, which inevitably leads to the revolt of the working class.

\section{Western Marxists critique of the alienation of consumption: excessive consumption}

During Marx's time, the consumption alienation is mainly manifested in the insufficient of consumption, namely the workers can only maintain animal's survival level of consumption. But after the Second World War, capitalist way of accumulation has changed by inducing workers to large amount of consumption. The shift is because the continuous increment of capital logic is blocked by insufficient consumption. The Capitalist realized those economic crises are also due to the lack of consumption. In order to make the logic of capital appreciation running smoothly, the capitalist countries began to improve the salary of workers and encourage them to consumption, so that they can realize the surplus value well and ensure the logic of continuous increment of capital operation. Thus, the expression of consumption alienation turns from the lack of consumption criticized by Marx to the excessive consumption criticized by Western Marxists.

As the global market is split up, the problem of insufficient consumption is becoming increasingly significant; the consumption cannot keep pace with production. As a result, the great economic crisis of capitalism broke out in 1929-1933, leading to the subsequent World War II. After the Second World War, the bourgeoisie began to find new strategies to alleviate class contradictions, stimulate consumption and cope with economic crisis. The new strategy is to raise the wages of the working class and to induce the workers to consumption. In this way, the bourgeoisie has not only alleviated class contradictions, but also provided sufficient consumer for the continuous operation of production.

Western Marxist scholars noticed the new change of the consumption policy implemented by the bourgeois. They see that the exploitation of workers has transformed from the production field to the consumption field. So the focus of criticism has thus changed from Marx's critique of labor alienation to the Western Marxist Scholars' critique of consumption alienation. The understanding of the alienation of consumption by western Marxist scholars is quite different from that of Marx's understanding of consumption alienation. Marx's understanding of consumption alienation is based on the capital of labor alienation caused by the lack of consumption, but the western Marxist scholars' understanding of consumption alienation is based on the abundance in the consumption of the masses.

In fact, the consumption alienation of excessive consumption is the result of capital logic. Before the Second World War, the consumption alienation of insufficient consumption is formed for the sake of capital accumulation. After the Second World War, the consumption alienation of excessive consumption is also the demand of the capital appreciation. Both kinds consumption alienation are all subject to the demand of the capital logic. Consumption alienation is the product of capitalist society, which is the result of capitalist private ownership. Both insufficient consumption and excessive consumption are the abnormal state of consumption, which can hinder people's liberation and development. Especially in the modern capitalist society, excessive consumption has become 
the main consumption alienation, so excessive consumption has become the focus of the western Marxist's criticism object.

\section{References}

[1] Karl Marx. The Economics and Philosophy Manuscript of 1844[M]. Beijing: people's press, 200018452545758595982.

[2] "Marx and Engels’ complete works" volume 30[M]. People's Press, 199531.

[3] Xianxin Hu. The Alienation of Capital and Consumption-on Marx's Theory of Consumption Alienation [J]. Journal of Philosophy and Dynamics, 2013(9) 16.

[4] "Marx and Engels’ Collected works" volume 5[M]. People's Press, 2009659. 